\title{
THERAPEUTIC EFFECTS OF Allium sativum AND Allium cepa IN Schistosoma mansoni EXPERIMENTAL INFECTION
}

Mona Mohamed MANTAWY, Hanan Farouk ALI \& Maha Zaki RIZK

\begin{abstract}
SUMMARY
The effects of both garlic (Allium sativum) and onion (Allium cepa) on some biochemical parameters in Schistosoma mansoni infected mice individually and mixed either with or without the currently used drug, praziquantel (PZQ) were investigated. These involved some immunological parameters, namely IgM, IgG, interleukins 2 and 6 (IL-2 and 6) and tumor necrosis factor (TNF- $\alpha$ ), some antioxidant enzymes [catalase, superoxide dismutase (SOD) and glutathione peroxidase (GPX)]. In addition, parasitological and histopathological investigations were performed. No changes were observed in the normal control mice treated with dry extract of onion or garlic, individually or mixed, with or without PZQ, compared to the normal healthy control group. Infection with S. mansoni showed an increase in IgG, IgM, IL-2, IL-6, TNF- $\alpha$ and catalase enzyme, accompanied with a decrease in GPX and SOD antioxidant enzyme activities. Remarkable amelioration was noticed in the levels of all the measured parameters in $S$. mansoni infected mice after administration of the studied extracts. Moreover a significant reduction in worm burden, hepatic and intestinal eggs and oogram count was noticed which was reflected in normalization of liver architecture.
\end{abstract}

KEYWORDS: Allium sativum; Allium cepa; Schistosoma mansoni; Experimental study; Therapeutic.

\section{INTRODUCTION}

Schistosomiasis is a widespread tropical disease with high morbidity and mortality, currently affecting over 200 million people worldwide (SIMEONOV et al., 2008). The body's defense against schistosome infection can take many forms. For example, upon developing acute schistosomiasis, patients often have fever coinciding with larval maturation, migration and oviposition. As the infection becomes established, the parasite comes under oxidative stress generated by the host immune system which is counteracted by the parasite antioxidant defense mechanism (ARAGON et al. 2008). Due to the lack of a vaccine, patient therapy is heavily reliant on chemotherapy with praziquantel as the World Health Organization-recommended drug, but concerns over drug resistance and possible reoccurrence of infection encouraged the search for new drug leads, possibly from natural resources (ABDULLA et al. 2007; ABEBE, 2008). In this concern RIZK et al. (2000) tested the efficiency of Curcuma longa extract against schistosomal infection and reported that these extracts possessed potent activity in reducing the liver disorders induced by the schistosome parasite. Interest in the potential benefits of garlic has its origin in antiquity as it is one of the earliest documented examples of plants used for maintenance of health and treatment of several diseases (RIVLIN, 2001). Previously, the antihelminthic effect of garlic has been verified by many investigators (HAMDY et al., 1983; MANSY, 1998; ABDEL-RAHMAN et al., 1998;
SUTTON \& HAIK, 1999; STRELIAEVA, 2000). EL-SHENAWY et al. (2008) showed that both garlic and Nigella sativa possessed promising antischistosomal activities. It has been reported that garlic (Allium sativum) and onion (Allium cepa) are used all over the world in different diseases, such as infections, injuries, gastrointestinal dysfunctions and cardiovascular diseases. METWALLY (2006) reported that treatment with either garlic or onion oils greatly normalized liver function enzymes and improved the antioxidant status in $S$. mansoni infection with a noticeable reduction in worm burden and egg count. The author concluded that treatment with these agents may act by improving the immunological host system. The present work aimed to undergo further studies on these plant extracts in a trial to demonstrate their role in reducing some undesirable disorders caused by schistosomiasis.

\section{MATERIAL AND METHODS}

Chemicals: The chemicals used were analar quality, products of Merck, Germany; Sigma, USA and El-Nasr Pharmaceutical Chemical Company, Egypt.

Animals: Ninety-six Swiss male albino mice of similar age and weight (20-25g) were selected for this study. They were obtained from Theodor Bilharz Research Institute, Cairo, Egypt. Animals were kept in a controlled environment and were allowed free access to food and water during the study. 


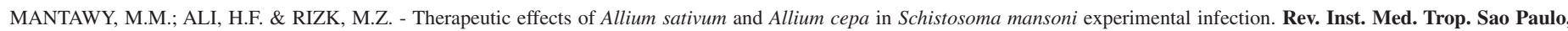
53(3): 155-63, 2011.

Preparation of onion (Allium cepa Linn.) and garlic (Allium sativum Linn.): Sliced onion and garlic pulps (3 $\mathrm{mm}$ thick) were dried at $50{ }^{\circ} \mathrm{C}$ overnight and pulverized in a mortar and pestle, the powder was kept dry and stored at $4{ }^{\circ} \mathrm{C}$ (MANTAWY \& MAHMOUD, 2002). Onion and garlic were administered in doses of $2 \mathrm{~g} / 100 \mathrm{~g}$ body weight daily for 45 days in a standard pelleted diet containing $24 \%$ protein, $4 \%$ fat and about 4-5\% fiber according to MANTAWY \& MAHMOUD (2002). Praziquantel was administered in a dose of $500 \mathrm{mg} / \mathrm{kg}$ body weight on two successive days after 45 days of infection (PIPER et al., 1990).

Experimental design: Duration of experiment was three months. Animals were divided into sixteen groups of six animals each. Groups 1-8 were normal healthy control mice while groups 9-16 were infected mice. Groups 2-8 were orally administered praziquantel, onion, garlic, onion + praziquantel, garlic + praziquantel, onion + garlic, and onion + garlic + praziquantel respectively. Group 9: Mice were infected with Egyptian strain of $S$. mansoni by direct skin contact through exposure to $80 \pm 10$ cercariae/mouse according to the method of OLIVER \& STIREWALT (1952) and sacrificed 45 days after the infection. Groups 10-16 were infected and treatment started 45 days post infection and continued for an extra period of 45 days as described, then mice were sacrificed. Mice were anesthetized using diethyl ether and the blood collected from the subtongual vein and the animals were then dissected and livers separated. The negative control groups (2-8) were administered their respective treatments simultaneously alongside the infected treated groups.

Blood samples were collected for serum separation by centrifugation at $1000 \mathrm{~g}$ for $15 \mathrm{~min}$, under cooling for the subsequent analysis of immunoglobulins, cytokines and antioxidant enzymes. Liver perfusion was performed for worm counting. Liver fragments were obtained for both egg count and histopathology. In addition intestinal fragments were obtained for oogram count.

Appropriate anesthetic and sacrifice procedures were followed ensuring that animals did not suffer at any stage of the experiments and complied according to legal ethical guidelines of the Ethical Committee of the Federal Legislation and National Institute of Health Guidelines in USA and approved by the Ethics Committee of the National Research Centre in Egypt.

\section{Parasitological parameters}

Worm count: Worms were recovered by hepatic perfusion as described by SMITHERS \& TERRY (1965). The percentage of reduction in worm numbers after challenge was calculated according to TENDLER et al. (1986) as follows:

\section{$\mathrm{P}=\mathrm{C}-\mathrm{V} / \mathrm{Cx} 100$}

Where $\mathrm{P}=$ percentage of protection, $\mathrm{C}=$ mean number of parasites recovered from infected animals and $\mathrm{V}=$ mean number of parasites recovered from treated animals.

Oogram: The oogram count was performed by microscopic examination of press preparations from three intestinal fragments (1 $\mathrm{cm}$ each) of infected animals. One hundred eggs were systematically counted per each fragment and classified according to different stages of development (PELLEGRINO et al., 1962).
Egg count: Egg count was demonstrated in the liver and intestine by taking a weighted portion of liver and intestine, plotted between two filter papers and each placed in a test tube containing $5 \mathrm{~mL}$ of $5 \% \mathrm{KOH}$ solution (CHEEVER \& ANDERSON, 1971). Eggs were counted after being spread on slides and number of eggs/g tissues was calculated.

Histopathology: Liver samples fixed in $10 \%$ formalin and paraffin blocks, ( $4 \mu \mathrm{m}$ thick) were prepared and stained with Hematoxylin and Eosin stains and then were studied histopathologically to evaluate structural alterations of the hepatic parenchymal cells and to clarify the presence of schistosome eggs and granuloma.

Determination of immunoglobulins titer: The developed sandwich ELISA was carried out according to MAGHRABY et al. (2007), using anti, IgG, IgM [ $2 \mu \mathrm{g} / \mathrm{mL}$ in phosphate buffers (PBS), $\mathrm{pH} 7.2]$.

Cellular immune response: Cytokine assay concentrations of TNF $\alpha$, IL-2, and IL- 6 in serum samples were determined by a sandwich ELISA. The assays were performed as suggested by the manufacturer, using purified antimouse cytokine mAbs (Pharmingen) to coat the microtitre plate and biotinylated antimouse cytokine mAbs (Pharmingen) as detecting antibodies (SMOLINSKI \& PESTKA, 2005).

\section{Determination of antioxidant enzymes}

Glutathione peroxidase (GPX): Determination of GPX was performed according to OZDEMIR et al. (2005). The oxidation of NADPH to NADP is accompanied by a decrease in absorbance at $340 \mathrm{~nm}$.

Catalase: The method applied was that employed by MOHANTY et al. (1997) and $\mathrm{H}_{2} \mathrm{O}_{2}$ produced was measured at 530nm.

Superoxide dismultase (SOD): SOD was measured according to UKEDA et al. (2002). The SOD activity can be determined by measuring the decrease in the color development at $440 \mathrm{~nm}$.

Statistical analysis: Data were analyzed by comparing values for different treatment groups with the values for individual controls. The significant differences among values were analyzed using analysis of variance (one-way Anova) coupled with post-hoc [Least significance difference (LSD) ] at $p \leq 0.05$.

\section{RESULTS}

Tables 1a and $\mathrm{b}$ and Figs. $1 \mathrm{a}$ and $\mathrm{b}$ revealed insignificant changes in IgG, IgM, antioxidant enzymes GPX, SOD, catalase and cytokines TNF- $\alpha$, IL-2, and IL-6, levels in normal healthy mice post various treatments. On the other hand, infection with Schistosoma mansoni showed a significant increase in $\operatorname{IgG}$, IgM, catalase, TNF- $\alpha$, IL-2, and IL6 which amounted to $+86.06,+37.14,+22.07+52.58,+210$ and $+360.28 \%$ respectively as compared to control group, while significant reduction was detected reaching -47.97 and $-34.36 \%$ for GPX and SOD, respectively. Significant amelioration is noticed in $\operatorname{IgG}, \operatorname{IgM}$ and catalase levels post different treatments (Table 2) recording the highest percentages of improvement with praziquantel given individually or combined with onion, garlic or both (groups 10, 13, 14 and 16). On the other hand, GPX and SOD show the highest percentages of enhancement with onion, garlic and their combination with or without praziquantel 


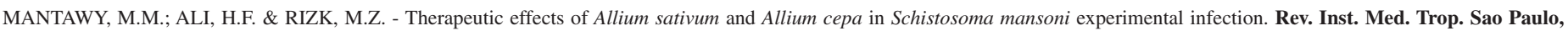
53(3): 155-63, 2011.

Table 1a

The level of immunoglobulins, cytokines and antioxidant enzymes in normal healthy mice treated with praziquantel (PZQ) with or without garlic (Allium sativum) and/or onion (Allium cepa).

\begin{tabular}{|c|c|c|c|c|c|c|c|c|}
\hline Groups & $\begin{array}{c}\text { Normal } \\
\text { Control (1) }\end{array}$ & $\begin{array}{l}\text { Normal control + } \\
\quad \operatorname{PZQ}(2)\end{array}$ & $\begin{array}{l}\text { Normal control + } \\
\text { onion }(3)\end{array}$ & $\begin{array}{l}\text { Normal control + } \\
\text { garlic (4) }\end{array}$ & $\begin{array}{c}\text { Normal control + } \\
\text { onion+ PZQ(5) }\end{array}$ & $\begin{array}{c}\text { Normal control + } \\
\text { garlic+ PZQ (6) }\end{array}$ & $\begin{array}{l}\text { Normal control }+ \\
\text { garlic }+ \text { onion }(7)\end{array}$ & $\begin{array}{c}\text { Normal control } \\
\text { onion + garlic + } \\
\text { PZQ (8) } \\
\end{array}$ \\
\hline $\begin{array}{l}\text { IgG } \\
\text { LSD } \\
\text { ANOVA } \\
\end{array}$ & $\begin{array}{c}1033.23 \pm 3.980 \\
(9,11,12,15) \\
(0.003) \\
\end{array}$ & $\begin{array}{c}1016.83 \pm 22.20 \\
(9,11,12,15) \\
(0.003) \\
\end{array}$ & $\begin{array}{c}1069.15 \pm 21.53 \\
(9,11,12,15) \\
(0.000) \\
\end{array}$ & $\begin{array}{c}1060.00 \pm 18.02 \\
(9,11,12,15) \\
(0.002) \\
\end{array}$ & $\begin{array}{c}1080.29 \pm 15.4 \\
(9,11,12,15) \\
(0.007) \\
\end{array}$ & $\begin{array}{c}1028.33 \pm 25.14 \\
(9,11,12,15) \\
(0.000) \\
\end{array}$ & $\begin{array}{c}1069.33 \pm 28.74 \\
(9,11,12,15) \\
(0.000) \\
\end{array}$ & $\begin{array}{c}1050.74 \pm 35.25 \\
(9,11,12,15) \\
(0.008) \\
\end{array}$ \\
\hline $\begin{array}{l}\text { IgM } \\
\text { LSD } \\
\text { ANOVA } \\
\end{array}$ & $\begin{array}{c}285.89 \pm 2.64 \\
(9,11,12) \\
(0.000)\end{array}$ & $\begin{array}{c}289.41 \pm 7.69 \\
(9,11,12) \\
(0.005) \\
\end{array}$ & $\begin{array}{c}284.0 \pm 8.66 \\
(9,11,12) \\
(0.000) \\
\end{array}$ & $\begin{array}{c}280.60 \pm 6.93 \\
(9,11,12) \\
(0.000) \\
\end{array}$ & $\begin{array}{c}288.00 \pm 14.73 \\
(9,11,12) \\
(0.000)\end{array}$ & $\begin{array}{c}283.16 \pm 8.03 \\
(9,11,12) \\
(0.000) \\
\end{array}$ & $\begin{array}{c}288.67 \pm 8.74 \\
(9,11,12,) \\
(0.000) \\
\end{array}$ & $\begin{array}{c}279.33 \pm 3.05 \\
(9,11,12,) \\
(0.000)\end{array}$ \\
\hline $\begin{array}{l}\text { GPX } \\
\text { LSD } \\
\text { ANOVA }\end{array}$ & $\begin{array}{c}1.23 \pm 0.006 \\
(9,10,15) \\
(0.000)\end{array}$ & $\begin{array}{c}1.02 \pm 0.003 \\
(3,4,5,6,7,8,9,11 \\
12,13,14,15,16) \\
(0.000)\end{array}$ & $\begin{array}{c}1.31 \pm 0.049 \\
(2,9,10) \\
(0.000)\end{array}$ & $\begin{array}{c}1.29 \pm 0.045 \\
(2,9,10) \\
(0.002) \\
\end{array}$ & $\begin{array}{c}1.27 \pm 0.043 \\
(2,9,10,15) \\
(0.005) \\
\end{array}$ & $\begin{array}{c}1.266 \pm 0.005 \\
(2,9,10,15) \\
(0.006)\end{array}$ & $\begin{array}{c}1.373 \pm 0.037 \\
(2,9,10,13,14) \\
(0.05)\end{array}$ & $\begin{array}{c}1.34 \pm 0.006 \\
(2,9,10) \\
(0.05)\end{array}$ \\
\hline $\begin{array}{l}\text { GAT } \\
\text { LSD } \\
\text { ANOVA } \\
\end{array}$ & $\begin{array}{c}10.42 \pm 0.13 \\
(9,11,12,13,15) \\
(0.000) \\
\end{array}$ & $\begin{array}{c}10.23 \pm 0.19 \\
(9,11,12,13,15) \\
(0.000) \\
\end{array}$ & $\begin{array}{c}11.14 \pm 0.12 \\
(9,14,16) \\
(0.000) \\
\end{array}$ & $\begin{array}{c}11.03 \pm 0.057 \\
(9,11,12,) \\
(0.000) \\
\end{array}$ & $\begin{array}{c}11.02 \pm 0.072 \\
(9,11,12) \\
(0.002) \\
\end{array}$ & $\begin{array}{c}11.03 \pm 0.057 \\
(9,11,12) \\
(0.003) \\
\end{array}$ & $\begin{array}{c}11.14 \pm 0.127 \\
(9,14,16) \\
(0.000)\end{array}$ & $\begin{array}{c}11.03 \pm 0.16 \\
(9,11,12) \\
(0.000) \\
\end{array}$ \\
\hline $\begin{array}{l}\text { SOD } \\
\text { LSD } \\
\text { ANOVA }\end{array}$ & $\begin{array}{c}1.95 \pm 0.024 \\
(9,10,11,12,13 \\
14,15,16) \\
(0.03)\end{array}$ & $\begin{array}{c}1.70 \pm 0.02 \\
(3,4,5,6,7,8,9,10 \\
11,12,13,14,15,16) \\
(0.03)\end{array}$ & $\begin{array}{c}1.99 \pm 0.11 \\
(2,5,6,8,9,10,11 \\
12,13,14,15,16) \\
(0.03) \\
\end{array}$ & $\begin{array}{c}1.96 \pm 0.055 \\
(2,5,6,9,10,11, \\
12,13,14,15,16) \\
(0.03)\end{array}$ & $\begin{array}{c}1.89 \pm 0.005 \\
(2,3,4,7,9,10,11,12 \\
13,14,15,16) \\
(0.03)\end{array}$ & $\begin{array}{c}1.88 \pm 0.015 \\
(2,3,4,7,9,10,11 \\
12,13,14,15,16) \\
(0.03) \\
\end{array}$ & $\begin{array}{c}2.03 \pm 0.06 \\
(2,5,6,8,9,10,11 \\
12,13,14,15,16) \\
(0.03) \\
\end{array}$ & $\begin{array}{c}1.92 \pm 0.04 \\
(2,3,7,9,10,11, \\
12,13,14,15,16) \\
(0.03)\end{array}$ \\
\hline $\begin{array}{l}\text { IL2 } \\
\text { LSD } \\
\text { ANOVA }\end{array}$ & $\begin{array}{c}126.02 \pm 0.68 \\
\text { (9) }\end{array}$ & $\begin{array}{c}126.0 \pm 2.65 \\
(9)\end{array}$ & $\begin{array}{c}135.67 \pm 3.15 \\
(9)\end{array}$ & $\begin{array}{c}135.30 \pm 2.56 \\
\text { (9) }\end{array}$ & $\begin{array}{c}126.00 \pm 7.42 \\
(9)\end{array}$ & $\begin{array}{c}129.80 \pm 4.48 \\
(9) \\
(0.003)\end{array}$ & $\begin{array}{c}139.96 \pm 0.94 \\
(9) \\
(0.000)\end{array}$ & $\begin{array}{c}131.79 \pm 1.59 \\
(2,5,7,9,10 . \\
11,13,15) \\
(0.001)\end{array}$ \\
\hline $\begin{array}{l}\text { INF } \alpha \\
\text { LSD } \\
\text { ANOVA } \\
\end{array}$ & $\begin{array}{c}0.60 \pm 0.010 \\
(9) \\
(0.000) \\
\end{array}$ & $\begin{array}{c}0.583 \pm 0.011 \\
(9) \\
(0.000) \\
\end{array}$ & $\begin{array}{c}0.630 \pm 0.030 \\
(9) \\
(0.009) \\
\end{array}$ & $\begin{array}{c}0.627 \pm 0.012 \\
(9) \\
(0.005) \\
\end{array}$ & $\begin{array}{c}0.600 \pm 0.01 \\
(9) \\
(0.012) \\
\end{array}$ & $\begin{array}{c}0.61 \pm 0.007 \\
(9) \\
(0.000) \\
\end{array}$ & $\begin{array}{c}0.64 \pm 0.015 \\
(9) \\
(0.006) \\
\end{array}$ & $\begin{array}{c}0.65 \pm 0.014 \\
(9,10,11,13) \\
(0.001)\end{array}$ \\
\hline $\begin{array}{l}\text { IL6 } \\
\text { LSD } \\
\text { ANOVA }\end{array}$ & $\begin{array}{c}25.88 \pm 0.68 \\
(9,12,15) \\
(0.000)\end{array}$ & $\begin{array}{c}25.593 \pm 0.51 \\
(9,12,15) \\
(0.000)\end{array}$ & $\begin{array}{c}27.82 \pm 0.23 \\
(9,15) \\
(0.000)\end{array}$ & $\begin{array}{c}27.71 \pm 0.42 \\
(9,15) \\
(0.000)\end{array}$ & $\begin{array}{c}26.55 \pm 0.51 \\
(9,15) \\
(0.000)\end{array}$ & $\begin{array}{c}26.52 \pm 0.42 \\
(9,15) \\
(0.000)\end{array}$ & $\begin{array}{c}28.51 \pm 0.50 \\
(9,15) \\
(0.006)\end{array}$ & $\begin{array}{c}27.37 \pm 0.54 \\
(9,15) \\
(0.001)\end{array}$ \\
\hline
\end{tabular}

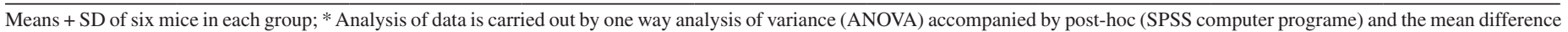
is significant at the 0.05 level; * IgG, IgM are expressed in $\mathrm{mg} / 100 \mathrm{~mL} ; *$ GPX, CAT and SOD are expressed in nmol/mL/min; * IL2, INFA and IL6 are expressed in pg/100mL

(groups 11, 12, 15 and 16) respectively. Concerning, IL-2 and IL6 the highest percentage of enhancement after treatment of infected mice with onion mixed with praziquantel was shown reaching $54.46 \%$ and $360.39 \%$ respectively. TNF- $\alpha$ recorded the highest percentage of improvement with garlic recording $211.67 \%$ followed by PZQ combined with onion and garlic (210.00\%) as compared to infected group.

Table 3, demonstrated significant reduction in egg count either in liver or intestine with all types of treatments recording the highest percentage rates of reduction in groups treated with praziquantel with or without onion, garlic or onion-garlic mixture (groups, 10, 13, 14 and 16) respectively. Nearly the same results were noticed in oogram for the same previously mentioned groups. Table 4 reveals that treatment with praziquantel with or without onion, garlic and onion-garlic showed the highest percentages of reduction in immature eggs (reaching zero percent in all cases) and the lowest percentages in dead and mature eggs reaching $87.3,88.5,89.2,91.7$ for dead eggs and $12.7,11.5,10.8$ and $8.3 \%$ respectively for mature ones. Concomitantly, worm burden (Table 5) showed the highest percentage in reduction rate amounting to 95.8 , $99.1,99.3$ and $99.7 \%$ respectively for the same groups. Histopathological examination of the liver sections of normal mice revealed the hepatic lobules formed of radially arranged cords of normal liver cells that radiated from central vein to the periphery of the lobule. The cell cords were separated by narrow blood sinusoid lined by endothelial cells and Kupffer cells (Fig. 2). The bilharzial liver (Fig. 3) showed the full-blown pathological picture of infection. Large lobular fibrocellular granuloma, focal areas of hepatic necrosis, cloudy swelling as well as degeneration of hepatocytes, were seen in some parts. The granulomatous lesions consisted of activated macrophages and epitheloid cells and attained large size surrounding ovum in the $2^{\text {nd }}$ month post infection. Liver sections of infected mice treated with PZQ together with onion-garlic mixture (Fig.4) showed fluctuated and noticeable degrees of improvement recording the highest enhancement level for praziquantel mixed with onion and garlic in comparison to infected group represented by small sized, late fibrocellular granuloma, in addition, decrease in cellular constituents, degenerative changes in eggs and pigments were minimal.

\section{DISCUSSION}

Previous studies have shown that the interaction between schistosome parasites and a human host is extremely complex. Many parasitologists have focused their studies on epidemiology or physiology of these parasites neglecting to some extent the metabolic relationship between parasites and the host in consequences to infection or drug treatment. The present results revealed insignificant changes in all parameters studied in normal healthy mice after various treatments. KYO (2001) suggested that garlic and onion extracts could be a promising candidate as an immune modifier, which maintains the homeostasis of immune function and the beneficial effect of both extracts can be considered as a possible means of immune system protection.

On the other hand, the host's response to $S$. mansoni infection involves 
MANTAWY, M.M.; ALI, H.F. \& RIZK, M.Z. - Therapeutic effects of Allium sativum and Allium cepa in Schistosoma mansoni experimental infection. Rev. Inst. Med. Trop. Sao Paulo, 53(3): 155-63, 2011.

Table 1b

The level of immunoglobulins, cytokines and antioxidant enzymes in infected and infected-treated mice with praziquantel (PZQ) with or without garlic (Allium sativum) and/or onion (Allium cepa)

\begin{tabular}{|c|c|c|c|c|c|c|c|c|}
\hline Groups & $\begin{array}{l}\text { Infected } \\
(9)\end{array}$ & $\begin{array}{c}\text { Infected - } \\
\text { PZQ } \\
(10) \\
\end{array}$ & $\begin{array}{c}\text { Infected - Onion } \\
\text { (11) }\end{array}$ & $\begin{array}{c}\text { Infected - Garlic } \\
\text { (12) }\end{array}$ & $\begin{array}{l}\text { Infected Onion } \\
\text { + PZQ (13) }\end{array}$ & $\begin{array}{l}\text { Infected Garlic } \\
\text { + PZQ (14) }\end{array}$ & $\begin{array}{l}\text { Infected onion } \\
+ \text { Garlic (15) }\end{array}$ & $\begin{array}{c}\text { Infected onion + } \\
\text { Garlic + PZQ (16) }\end{array}$ \\
\hline $\begin{array}{l}\text { IgG } \\
\text { LSD }\end{array}$ & $\begin{array}{c}1922.633 \pm 0.98 \\
(1,2,3,4,5,6,7,8,10 \\
11,12,13,14,15,16)\end{array}$ & $\begin{array}{l}1041 \pm 54.30 \\
(9,11,12,15)\end{array}$ & $\begin{array}{c}1286.00 \pm 61.86 \\
(1,2,3,4,5,6,7,8,9 \\
10,13,14,16)\end{array}$ & $\begin{array}{c}1254.62 \pm 65.41 \\
(1,2,3,4,5,6,7,8 \\
9,10,13,14,16)\end{array}$ & $\begin{array}{c}1065.99 \pm 60.79 \\
(9,11,12,15)\end{array}$ & $\begin{array}{c}1049.38 \pm 65.135 \\
(9,11,12,15)\end{array}$ & $\begin{array}{c}1207.77 \pm 68.00 \\
(1,2,3,4,5,6,7,8 \\
9,10,13,14,16)\end{array}$ & $\begin{array}{c}1038.56 \pm 66.91 \\
(9,11,12,15)\end{array}$ \\
\hline ANOVA & $(0.000)$ & $(0.002)$ & $(0.000)$ & $(0.000)$ & $(0.001)$ & $(0.000)$ & $(0.001)$ & $(0.000)$ \\
\hline $\begin{array}{l}\text { IgM } \\
\text { LSD }\end{array}$ & $\begin{array}{c}392.07 \pm 11.94 \\
(1,2,3,4,5,6,7,8,10 \\
11,12,13,14,15,16)\end{array}$ & $\begin{array}{c}275.57 \pm 14.37 \\
(9,11,12)\end{array}$ & $\begin{array}{c}330.80 \pm 17.35 \\
(1,2,3,4,5,6,7,8 \\
9,10,13,14,15,16)\end{array}$ & $\begin{array}{c}319.176 \pm 13.14 \\
(1,2,3,4,5,6,7,8,9 \\
10,13,14,15,16)\end{array}$ & $\begin{array}{c}274.490 \pm 12.85 \\
(9,11,12)\end{array}$ & $\begin{array}{c}273.876 \pm 13.24 \\
(9,11,12)\end{array}$ & $\begin{array}{c}284.04 \pm 20.02 \\
(9,11,12)\end{array}$ & $\begin{array}{c}270.89 \pm 17.05 \\
(9,11,12)\end{array}$ \\
\hline ANOVA & $(0.000)$ & $(0.000)$ & $(0.000)$ & $(0.000)$ & $(0.000)$ & $(0.000)$ & $(0.000)$ & $(0.000)$ \\
\hline $\begin{array}{l}\text { GPX } \\
\text { LSD } \\
\text { ANOVA }\end{array}$ & $\begin{array}{c}0.64 \pm 0.03 \\
(1,2,3,4,5,6,7,8,10, \\
11,12,13,14,15,16) \\
(0.000)\end{array}$ & $\begin{array}{c}1.11 \pm 0.006 \\
(1,3,4,5,6,7,8,9,11, \\
12,13,14,15,16) \\
(0.000)\end{array}$ & $\begin{array}{c}1.27 \pm 0.005 \\
(2,9,10,15) \\
(0.05)\end{array}$ & $\begin{array}{c}1.34 \pm 0.0076 \\
(2,9,10) \\
(0.05)\end{array}$ & $\begin{array}{c}1.24 \pm 0.0049 \\
(2,7,9,10,15) \\
(0.05)\end{array}$ & $\begin{array}{c}1.26 \pm 0.0055 \\
(2,7,9,10,15) \\
(0.05)\end{array}$ & $\begin{array}{c}1.395 \pm 0.0053 \\
(1,2,5,6,9,10,11 \\
13,14) \\
(0.05)\end{array}$ & $\begin{array}{c}1.33 \pm 0.0046 \\
(2,9,10) \\
(0.05)\end{array}$ \\
\hline $\begin{array}{l}\text { GAT } \\
\text { LSD } \\
\text { ANOVA }\end{array}$ & $\begin{array}{c}12.72 \pm 0.17 \\
(1,2,3,4,5,6,7,8,10, \\
11,12,13,14,16) \\
(0.000)\end{array}$ & $\begin{array}{l}11.07 \pm 0.15 \\
\quad(9,11) \\
(0.000)\end{array}$ & $\begin{array}{c}11.39 \pm 0.15 \\
(1,2,4,5,6,8,9, \\
10,14,16) \\
(0.000)\end{array}$ & $\begin{array}{c}11.24 \pm 0.16 \\
(1,2,4,5,6,8,9 \\
14,16) \\
(0.000)\end{array}$ & $\begin{array}{c}11.00 \pm 0.15 \\
(1,2,9,16) \\
(0.000)\end{array}$ & $\begin{array}{c}10.90 \pm 0.16 \\
(9,10,11,12,15) \\
(0.000)\end{array}$ & $\begin{array}{c}11.15 \pm 0.17 \\
(1,2,9,14,16) \\
(0.000)\end{array}$ & $\begin{array}{c}10.85 \pm 0.16 \\
(9,11,12,13,15) \\
(000)\end{array}$ \\
\hline $\begin{array}{l}\text { SOD } \\
\text { LSD } \\
\text { ANOVA } \\
\end{array}$ & $\begin{array}{c}1.28 \pm 0.023 \\
(1,2,3,4,5,6,7,8,10, \\
11,12,13,14,15,16) \\
(0.033) \\
\end{array}$ & $\begin{array}{c}1.51 \pm 0.02 \\
(1,2,3,4,5,6,7,8,9 \\
11,12,13,14,15,16) \\
(0.033) \\
\end{array}$ & $\begin{array}{c}2.49 \pm 0.030 \\
(1,2,3,4,5,6,7,8,9,10 \\
11,12,13,14,15,16) \\
(0.033)\end{array}$ & $\begin{array}{c}2.63 \pm 0.03 \\
(1,2,3,4,5,6,7,8,9 \\
10,11,13,14,15) \\
(0.033) \\
\end{array}$ & $\begin{array}{c}2.19 \pm 0.026 \\
(1,2,3,4,5,6,7,8,9,10 \\
11,12,15,16) \\
(0.033)\end{array}$ & $\begin{array}{c}2.22 \pm 0.02 \\
(1,2,3,4,5,6,7,8,9, \\
10,11,12,15,16) \\
(0.033)\end{array}$ & $\begin{array}{c}2.73 \pm 0.02 \\
(1,2,3,4,5,6,7,8,9 \\
10,11,12,13,14,16) \\
(0.033) \\
\end{array}$ & $\begin{array}{c}2.61 \pm 0.035 \\
(1,2,3,4,5,6,7,8,9,10, \\
11,13,14,15) \\
(0.003)\end{array}$ \\
\hline $\begin{array}{l}\text { IL2 } \\
\text { LSD }\end{array}$ & $\begin{array}{c}192.28 \pm 0.01 \\
(1,2,3,4,5,6,7,8,10, \\
11,12,13,14,15,16)\end{array}$ & $\begin{array}{c}135.43 \pm 0.59 \\
(9)\end{array}$ & $\begin{array}{c}125.83 \pm 0.67 \\
(9)\end{array}$ & $\begin{array}{c}133.04 \pm 0.72 \\
(9)\end{array}$ & $\begin{array}{c}123.64 \pm 0.67 \\
(9)\end{array}$ & $\begin{array}{l}130.45 \pm 1.32 \\
(9)\end{array}$ & $\begin{array}{c}136.55 \pm 1.38 \\
(9)\end{array}$ & $\begin{array}{l}1.29 \pm 1.31 \\
(9)\end{array}$ \\
\hline $\begin{array}{l}\text { ANOVA } \\
\text { INF } \alpha \\
\text { LSD }\end{array}$ & $\begin{array}{c}(0.000) \\
1.86 \pm 0.46 \\
(1,3,4,5,6,7,8,10, \\
11,12,13,14,15,16)\end{array}$ & $\begin{array}{c}(0.000) \\
0.61 \pm 0.058 \\
(9)\end{array}$ & $\begin{array}{c}(0.000) \\
0.66 \pm 0.009 \\
(9)\end{array}$ & $\begin{array}{c}(0.002) \\
0.59 \pm 0.01 \\
(, 9)\end{array}$ & $\begin{array}{c}0.63 \pm 0.0085 \\
(9)\end{array}$ & $\begin{array}{c}(0.003) \\
0.64 \pm 0.02 \\
(9)\end{array}$ & $\begin{array}{c}(0.000) \\
0.67 \pm 0.01 \\
(9)\end{array}$ & $\begin{array}{c}(0.004) \\
0.60 \pm 045 \\
(9)\end{array}$ \\
\hline ANOVA & $(0.000)$ & $(0.000)$ & $(0.001)$ & $(0.008)$ & $(0.006)$ & & $(0.000)$ & $(0.000)$ \\
\hline $\begin{array}{l}\text { IL6 } \\
\text { LSD }\end{array}$ & $\begin{array}{c}119.12 \pm 0.68 \\
(1,2,3,4,5,6,7,8,10 \\
11,12,13,14,15,16)\end{array}$ & $\begin{array}{l}27.98 \pm 0.21 \\
(9,15)\end{array}$ & $\begin{array}{l}28.48 \pm 0.29 \\
\quad(9,15)\end{array}$ & $\begin{array}{c}31.56 \pm 0.32 \\
\quad(1,2,9)\end{array}$ & $\begin{array}{c}25.85 \pm 0.34 \\
(9,12,15)\end{array}$ & $\begin{array}{l}27.34 \pm 0.72 \\
(9,15)\end{array}$ & $\begin{array}{c}33.33 \pm 0.87 \\
(1,2,3,4,5,6,7,8,9 \\
10,11,13,14,16)\end{array}$ & $\begin{array}{l}27.23 \pm 0.71 \\
(9,15)\end{array}$ \\
\hline ANOVA & $(0.000)$ & $(0.000)$ & $(0.007)$ & $(0.000)$ & $(0.000)$ & $(0.002)$ & $(0.000)$ & $(0.003)$ \\
\hline
\end{tabular}

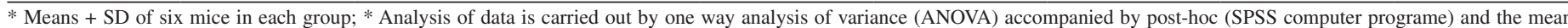

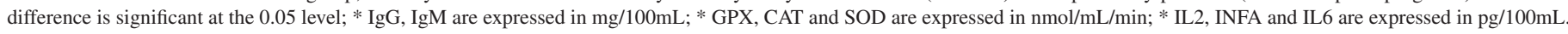

the production of reactive oxygen species where the antioxidant enzymes represent a target for immune elimination of adult worms (LOVERDE, 1998). The present data revealed significant elevation in immunoglobulins, IgG, IgM, catalase, the cytokines IL-2, IL-6 and TNF- $\alpha$, with significant diminution in GPX, peroxidase, SOD, after infection with S. mansoni. The present results are in agreement with several workers who demonstrated that schistosome infection elicits a very intense humoral response among which the massive production of anaphylactic antibodies is striking. Both IgG and IgM are increased significantly in the host in response to a challenge infection (GRZYCH et al., 1982; CAPRON et al., 1983). In addition, CANALS et al. (1997) showed a decrease in the percentage of $\mathrm{CD}^{+}$cells, and an increase in the percentage of $\mathrm{IgM}, \mathrm{IgG}$ cells and cells bearing the TcR1 marker. These changes were coincident with an increase in the proportion of activated IL-2 and IL-6. More recently, JIA et al. (2009) attributed the significant elevation in immunoglobulins in schistosomaisis to the decrease in ROS scavenging capacity by antioxidants to the extent that constant oxidative stress develops and oxidation of lipids, protein and other macromolecules such as DNA is increased.

Moreover the present results indicate that infection with S. mansoni impairs the antioxidant system reflected in the depleted level of glutathione peroxidase which is used as an index of oxidative stress and a sign that hepatic cells are utilizing more antioxidant defenses (IP et al., 2000; ALI, 2007). Accordingly, HAMED (2006) found that glutathione level decreased after parasitic infection and GHARIB et al. (1999) attributed the decreased level of glutathione to the increased cytoxtocity with $\mathrm{H}_{2} \mathrm{O}_{2}$ which is produced as a result of inhibition of glutathione reductase that keeps glutathione in its reduced form. PASCAL et al. (2000) and SOLIMAN et al. (2000) reported that oxidative stress due to schistosomiasis causes an elevation in lipid peroxides, since the complex mechanism of lipid peroxidation is known to require the participation of highly reactive oxygen and other reactive oxygen metabolites in the chain of biochemical reactions, thus whenever these free radicals are involved, lipid peroxides are in turn increased. Hence, lipid peroxides serve as a marker of cellular oxidative stress and has long been recognized as a major consecutive factor of oxidative damage in chronic diseases (SON et al., 2007). The present results obtained for antioxidant enzyme levels are in accordance to several authors who found significant reduction in SOD and GPX with higher levels of catalase in serum and liver of infected mice, and attributed these changes to the number of deleterious effects due to the accumulation of superoxide radicals and hydrogen peroxide (PEDRAZA-CHAVERRI, 2001; KUNTZ et al., 2007). The elevated levels of catalase may serve as one way for the hepatic antioxidative 


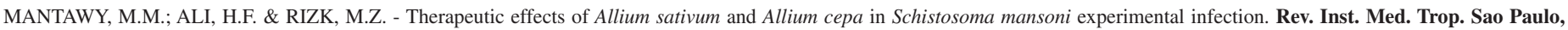
53(3): $155-63,2011$.
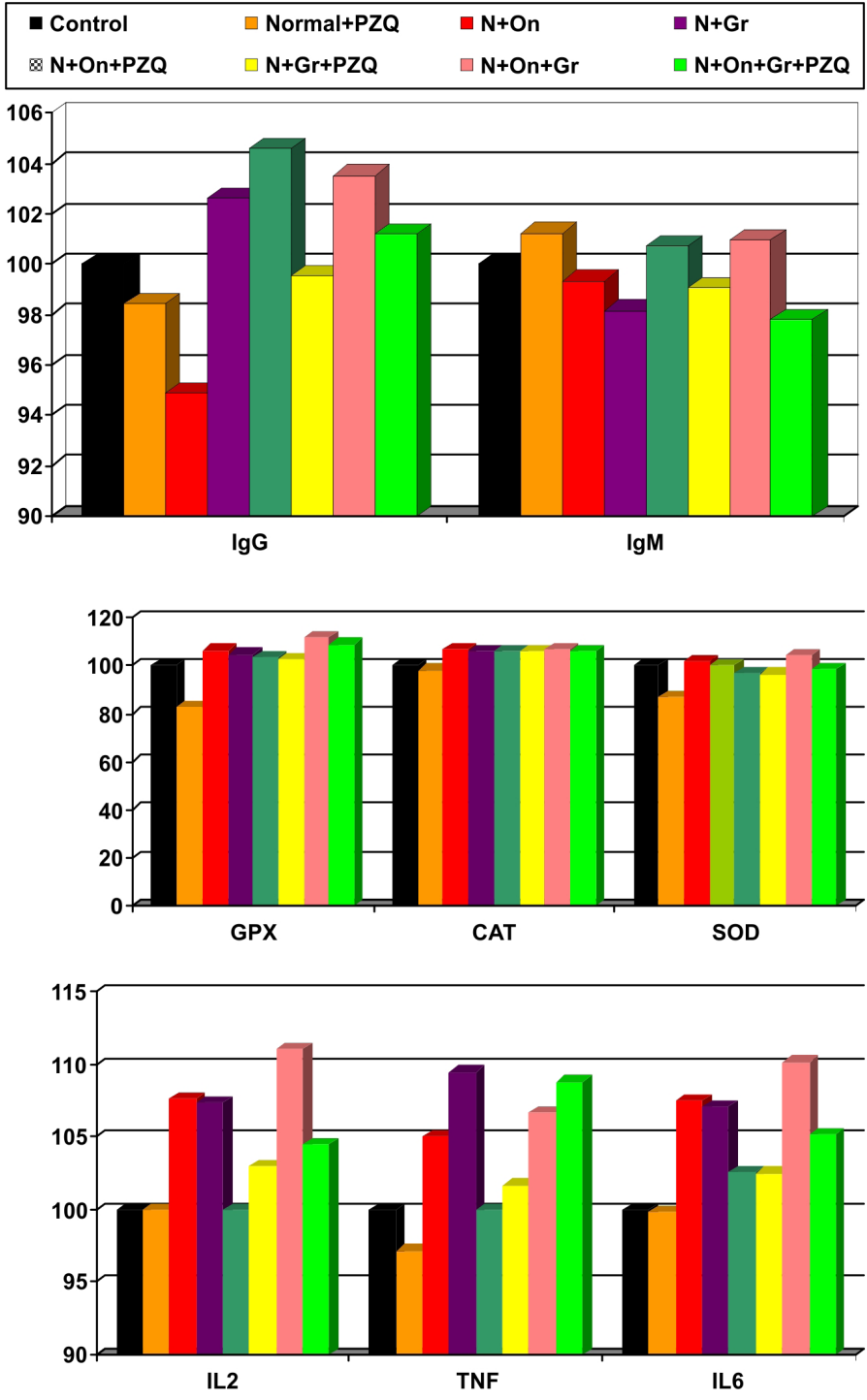

Fig. 1 (a) - \% change in normal treated groups as compared to normal untreated one.
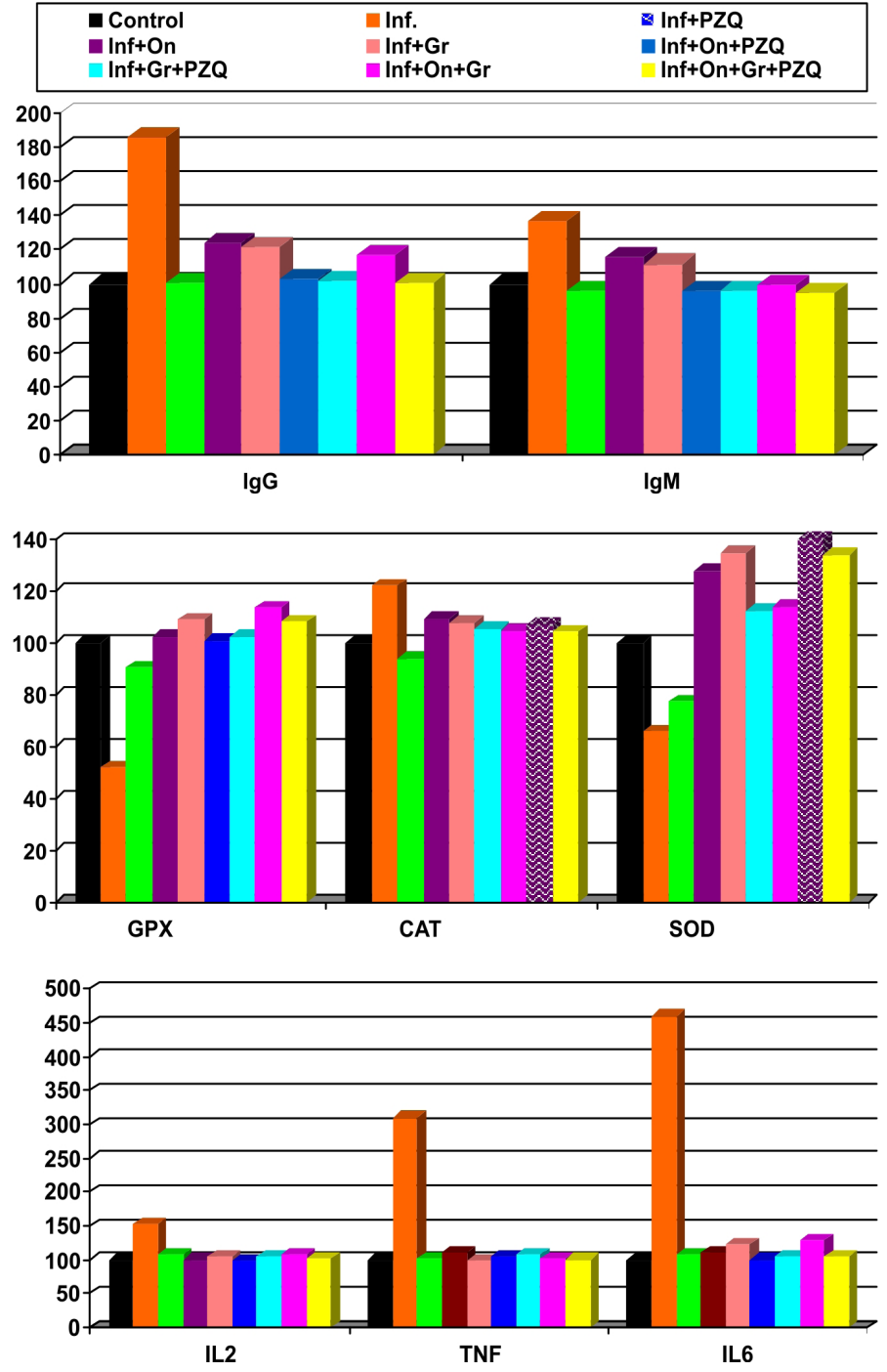

Fig. 1 (b) - \% change in infected and different infected-treated groups as compared to normal untreated one.

Table 2

$\%$ of improvement in different infected-treated groups

\begin{tabular}{|c|c|c|c|c|c|c|c|}
\hline$\underbrace{\text { Parameters }}_{\text {groups }}$ & Inf+ PZQ & Inf+onion & Inf+garlic & Inf+onion+ PZQ & $\begin{array}{c}\text { Inf+garlic } \\
+ \text { PZQ }\end{array}$ & $\begin{array}{l}\text { Inf+onion } \\
\text { +garlic }\end{array}$ & $\begin{array}{l}\text { Inf+onion+ } \\
\text { garlic+ PZQ }\end{array}$ \\
\hline $\operatorname{IgG}$ & 85.29 & 61.57 & 64.61 & 82.96 & 84.51 & 69.14 & 85.52 \\
\hline $\operatorname{IgM}$ & 40.75 & 21.43 & 25.44 & 41.13 & 41.34 & 37.79 & 42.39 \\
\hline GPX & 38.211 & 51.22 & 56.91 & 48.78 & 50.41 & 61.38 & 56.10 \\
\hline CAT & 15.83 & 12.76 & 14.20 & 16.51 & 17.47 & 15.07 & 17.95 \\
\hline SOD & 11.79 & 62.05 & 69.23 & 46.67 & 48.21 & 74.36 & 68.21 \\
\hline IL2 & 45.11 & 52.73 & 47.00 & 54.46 & 49.06 & 44.22 & 50.21 \\
\hline $\mathrm{INF} \alpha$ & 208.33 & 200 & 211.67 & 205 & 203.33 & 198.33 & 210 \\
\hline IL6 & 352.16 & 350.23 & 338.33 & 360.39 & 354.64 & 331.49 & 355.06 \\
\hline
\end{tabular}


MANTAWY, M.M.; ALI, H.F. \& RIZK, M.Z. - Therapeutic effects of Allium sativum and Allium cepa in Schistosoma mansoni experimental infection. Rev. Inst. Med. Trop. Sao Paulo, 53(3): 155-63, 2011.

Table 3

Ova load in different groups received praziquantel with or without onion, garlic individually or mixed

\begin{tabular}{|c|c|c|c|c|}
\hline Animal groups & Hepatic ova & $\%$ of red $(\mathrm{L})$ & Intestinal Ova & $\begin{array}{c}\% \text { of } \\
\text { reduction (1) }\end{array}$ \\
\hline Infected & $9600 \pm 71.0$ & - & $13080 \pm 89.31$ & - \\
\hline Infected + PZQ & $890 * * * \pm 42.0$ & 90.7 & $820 * * * \pm 38.81$ & 93.8 \\
\hline Infected + onion & $2890 * * * \pm 54.25$ & 69.89 & $4020 * * * \pm 4.36$ & 69.27 \\
\hline Infected + onion + PZQ & $802 * * * \pm 62.32$ & 91.6 & $827 * * * \pm 85.21$ & 93.7 \\
\hline Infected + garlic & $2600 * * * \pm 79.0$ & 72.92 & $3589 * * * \pm 64.42$ & 72.56 \\
\hline Infected + Garlic + PZQ & $774 * * * \pm 54.3$ & 91.9 & $897 * * * \pm 35.78$ & 93.3 \\
\hline Infected + Garlic + onion & $2050 * * * \pm 69.0$ & 78.65 & $3130 * * * \pm 69.42$ & 76.07 \\
\hline Infected + Garlic + onion + PZQ & $724 * * * \pm 61.45$ & 92.45 & $815^{* * *} \pm 48.65$ & 93.8 \\
\hline
\end{tabular}

***Highly significant difference as compared to infected group, where $\mathrm{p} \leq 0.001$; -Mean \pm SD of five mice in each group; Statistical analysis is carried out by Student T-test, where significant level at $\mathrm{p} \leq 0.05$.

Table 4

The oogram pattern in infected and treated mice

\begin{tabular}{lccc}
\hline Animal group & $\%$ immature ova & $\%$ mature ova & $\%$ dead ova \\
\hline Infected & $51.7 \pm 4.3$ & $42 \pm 3.7$ & $6.3 \pm 0.9$ \\
Inf. + PZQ & $0 * * *$ & $12.7 \pm 1.3 * * *$ & $87.3 \pm 3.5 * * *$ \\
Inf. + onion & $20 \pm 1.2 * * *$ & $10.5 \pm 0.3 * * *$ & $69.5 \pm 1.2^{* * *}$ \\
$\begin{array}{l}\text { Inf. + onion + } \\
\text { PZQ }\end{array}$ & $0 * * *$ & $11.5 \pm 0.2 * * *$ & $88.5 \pm 6.5 * * *$ \\
$\begin{array}{l}\text { Infected + garlic } \\
\text { Infected + Garlic } \\
+ \text { PZQ }\end{array}$ & 0 15.8*3.4*** & $7.5 \pm 0.6 * * *$ & $76.7 \pm 2.3^{* * *}$ \\
$\begin{array}{l}\text { Infected + Garlic } \\
+ \text { onion }\end{array}$ & $12 \pm 2.9^{* * * *}$ & $4 \pm 0.8 \pm 1.3 * * *$ & $89.2 \pm 4.4 * * *$ \\
$\begin{array}{l}\text { Infected + Garlic } \\
+ \text { onion + PZQ }\end{array}$ & $0 * * *$ & $8.3 \pm 1.2 * * *$ & $91.7 \pm 4.7 * * *$ \\
\hline
\end{tabular}

Statistically significant difference as compared to infected control at $\mathrm{p}<0.001$; Results are expressed as mean $(\mathrm{M}) \pm$ standard deviation (SD) of five animals; Statistical analysis is carried out by Student T-test, where significant level at $\mathrm{p} \leq 0.05$. system to keep homeostasis and protect against oxidative damage since catalase is considered one of two major scavenging enzymes that remove toxic free radicals in vivo (EL-SHENAWY et al., 2008 ; JIA et $a l ., 2009)$. These dramatic changes in infectious state can be explained on the basis of $S$. mansoni eggs trapped in the host liver which elicit a chain of oxidative processes that may be, at least in part, responsible for the pathology and progression of fibrosis associated with schistosomal infection. The significant improvement in the previously mentioned parameters after treatment of infected mice with praziquantel resulted from the significant reduction in worm burdens (95.8\%) accompanied with significant increase in percentage of dead ova $(87.3 \%)$ and a decrease in the percentage of mature ova stages $(12.7 \%)$, reduction in hepatic and intestinal oogram (by 90.7 and $93.8 \%$ respectively) as well as liver granuloma size (as indicated by Fig. 4) compared with the $S$. mansoni infected group. The antischistosomal drug, PZQ causes worm tegument damage (that is accompanied by a large influx of calcium into worms leading to muscular contraction, surface disruption and eventual death of the parasite) that consequently limit or enhance significantly immune response of patients and generate a reversion of the level of fibrosis (BOTROS et al., 2006). Thereby as evidenced by several studies the significant reduction in oxidative stress initiates a positive impact on the preservation of liver integrity and function, antioxidant enzymes,

Table 5

Worm load, in S. mansoni infected mice and treated with onion, garlic individually or mixed with or without PZQ

\begin{tabular}{|c|c|c|c|c|c|}
\hline \multirow{2}{*}{ Animal } & \multicolumn{3}{|c|}{ Mean worm burden \pm SD (liver and porto-mesenteric) } & \multirow{2}{*}{ Total worm burden } & \multirow{2}{*}{$\%$ parasite reduction } \\
\hline & Male & Female & Couples & & \\
\hline Infected & $8.8 \pm 1.51$ & $5.11 \pm 0.79$ & $5.4 \pm 0.76$ & $24.71 \pm 2.25$ & \\
\hline Inf. + PZQ & $0.83 \pm 0.49$ & $0.21 \pm 0.12$ & 0 & $1.04 \pm 0.2 * * *$ & 95.8 \\
\hline Inf.+ onion & $3.5 \pm 0.95$ & $2.00 \pm 0.82$ & $2.83 \pm 0.65$ & $8.33 \pm 2.44 * * *$ & 66.29 \\
\hline Inf.+ onion + PZQ & $0.22+0.01$ & 0 & 0 & $0.22 \pm 0.01 * * *$ & 99.1 \\
\hline Inf. + garlic & $2.55 \pm 0.58$ & $2.2 \pm 0.31$ & $1.82 \pm 0.42$ & $6.57 \pm 0.37 * * *$ & 73.41 \\
\hline Inf. + garlic + PZQ & $0.17 \pm 0.06$ & 0 & 0 & $0.17 \pm 0.06^{* * *}$ & 99.3 \\
\hline Inf. + garlic + onion & $1.75 \pm 0.38$ & $1.8 \pm 0.25$ & $2.72 \pm 0.26$ & $6.27 \pm 0.28 * * *$ & 74.63 \\
\hline Inf. + garlic + onion + PZQ & $0.08 \pm 0.03$ & 0 & 0 & $0.08 \pm 0.03 * * *$ & 99.7 \\
\hline
\end{tabular}

Statistically significant difference as compared to infected control at $\mathrm{p}<0.001$; Results are expressed as mean (M) \pm standard deviation (SD) of five animals. Statistical analysis is carried out by Student T-test, where significant level at $\mathrm{p} \leq 0.05$. 


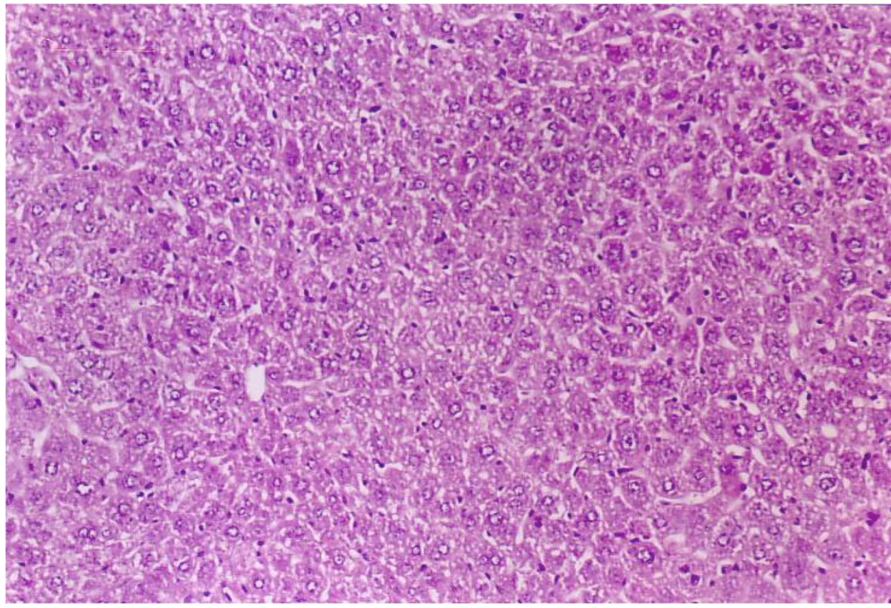

Fig. 2 - Liver section of a normal mouse showing polyhedral hepatocytes forming a network of hepatic strands around the central vein. Each hepatocyte encloses a finely granulated cytoplasm with a round and centrally located nucleus. Hepatic cords are interspersed by narrow blood sinusoids lined by occasional Kupffer cells $(\mathrm{H} \& \mathrm{E} \times 200)$.

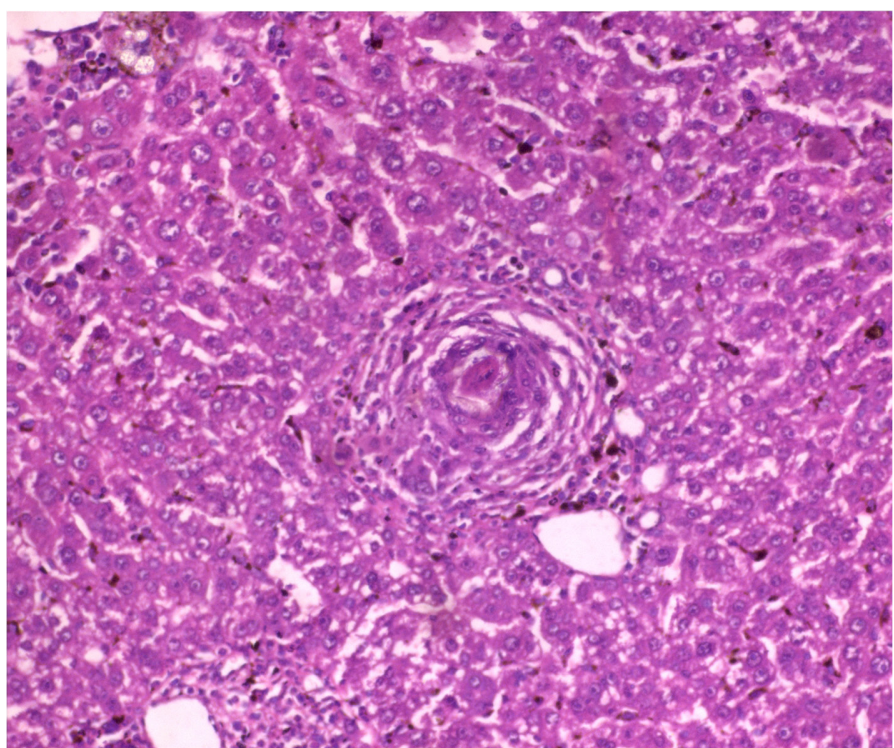

Fig. 3 - Liver section from an eight-week infected control mouse showing large fibrocellular granuloma. H \& E. X 200

immunoglobulin profile ( $\operatorname{IgG}$ and $\operatorname{IgM}$ ), interleukins and tumor necrosis factors (PICA-MATTOCCIA et al., 2008).

MORALES-MONTOR et al. (2001) have implicated TNF- $\alpha$ as the major cytokine responsible for granuloma formation. A possible mechanism by which TNF- $\alpha$ controls granuloma formation, is the up-regulation of intracellular adhesion molecule 1 (ICAM-1), which mediates cell-cell interactions and migration across the endothelium. While TNF- $\alpha$ is important for initiating granuloma formation, other mediators play a role in the full expression of the lesion under normal conditions. Because parasite eggs induce a strong type- 2 response, it was hypothesized initially that type- 2 rather than type- 1 cytokines play an integral role in granuloma formation. It has now become apparent that in the mouse model, under experimental conditions, both type- 1 and type- 2

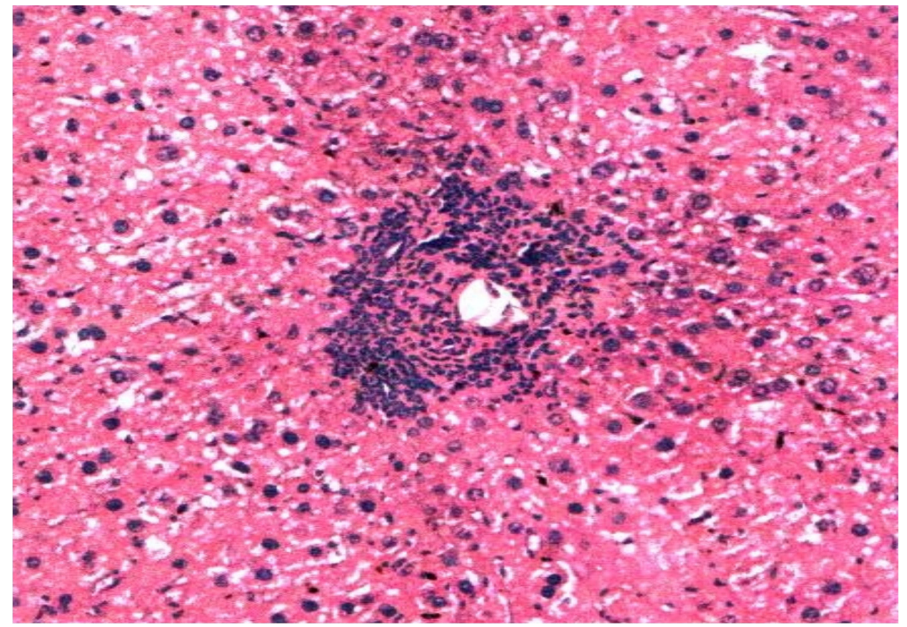

Fig. 4 - Liver section of infected mice treated with PZQ+ onion and garlic showing small size late fibrocellular granuloma, in addition, decreased cellular constituents, degenerative changes in the ova and the pigments were minimal. (H \& E $\times 200)$

cytokines can orchestrate granuloma development, albeit with differences in the size of induced lesions. Specifically, dominant type- 2 response mediates the formation of larger granulomas, whereas dominant type-1 response leads to the development of smaller lesions. Previous studies have viewed hepatic granuloma size as an indicator of morbidity, with larger lesions detrimental and smaller ones an ideal compromise between egg-sequestration and tissue pathology, production of type-1 rather than type- 2 cytokines during infection has been considered preferable. It is perhaps pertinent to point out that granuloma size is not a deciding factor in categorizing human disease where, instead, the degree of fibrosis indicates disease severity (BRUNET et al., 1998).

The mechanisms whereby the consumption of certain plants and plant extract can affect parasite viability, mobility and fecundity both in vivo and in vitro could be associated with an enhanced immune response of the host towards the parasites, as a result of nutrient supplementation and thus improved nutrition. It is known that high dietary protein intake in animals can enhance the immune response of ruminants towards parasites. However, it appears that many plants that have been reported to have anthelmintic properties actually contain compounds that are directly active against parasites. In many cases these active compounds are secondary metabolites, i.e. plant products that have been associated with defensive mechanisms. Saponin, alkaloids, non-protein amino acids, tannins and other polyphenols, liginin, glycolides are all secondary metabolites and some of them have been considered responsible for the anti-parasitic effect of plants. In this regard, garlic and onion contain sulphuric compounds which have been considered responsible for the anthelmintic effect (GITHIORI et al., 2006). The antischistosomal effect of either garlic or onion may be attributed to their effect on the host immune response as reported by GHAZANFARI et al.(2006). They contain an immunomodulator fraction, which affects the course of infection and shifts the cytokine pattern from Th2-lymphocytes mediated immune response, responsible for granuloma formation, to Th1-lymphocytes - mediated immune responses, responsible for immune resistance (GHAZANFARI et al., 2000). Our data demonstrated that treatment with either garlic, onion and their mixture were effective in considerably reducing worm burden, hepatic and intestinal eggs and 
MANTAWY, M.M.; ALI, H.F. \& RIZK, M.Z. - Therapeutic effects of Allium sativum and Allium cepa in Schistosoma mansoni experimental infection. Rev. Inst. Med. Trop. Sao Paulo, 53(3): 155-63, 2011.

oogram. In addition a conspicuous suppression in granuloma tissue formation and diminutive histopathological changes, indicate their antischistosomicidal activities and curative effect on S. mansoni infection. The reduction in egg count in our study may be attributed to the reduction in worm burden and/or these nutrients may affect the ability of both male and female worm maturity (through their effect on gonads) to couple and consequently affect egg output by a female adult worm. These results are in harmony with other investigators who used extracts including garlic and onion for the treatment of parasitic infection (ABU-EL-EZZ, 2005; GHAZANFARI et al., 2006; RIAD et al., 2007).

The main cause of mortality and morbidity in human schistosomiasis is hepatic fibrosis which is essentially dependent on granulomas (WARREN, 1978). Granulomatous inflammation in schistosomiasis is a cell mediated hypersensitivity to parasitic egg antigens that are lodged in hepatic tissue (WARREN et al., 1967). Administration of onion and/or garlic in the present study resulted in reduction in egg deposition, hence improved liver architecture and prevented or attenuated the decrease in tissue antioxidant enzymes. Hence, these extracts may provide cellular protection against reactive oxygen species arising due to infection.

In conclusion, normal control mice treated with onion, garlic individually or mixed with or without PZQ, showed insignificant change of all parameters studied compared to the normal healthy control group. Infection with $S$. mansoni exhibited significant increases in IgG, IgM, IL2 , IL-6, TNF- $\alpha$ and catalase enzyme, with significant reduction in GPX and SOD antioxidant enzymes. Significant amelioration was noticed in the levels of all the measured parameters in $S$. mansoni infected mice as a result of treatment with the previously reported nutrients with significant reduction in worm burden, hepatic and intestinal eggs and oogram count that help in persevering and normalizing liver architecture.

\section{RESUMO}

\section{Efeitos terapêuticos do Allium sativum e Allium cepa na infecção experimental pelo Schistosoma mansoni}

Os efeitos do alho (Allium sativum) e cebola (Allium cepa) em parâmetros bioquímicos de camundongos infectados pelo Schistosoma mansoni individualmente e misturados seja com ou sem as drogas correntemente usadas como o Praziquantel (PZQ), foram investigados. Isto envolveu parâmetros imunológicos tais como $\operatorname{IgM}$, IgG, Interleucina 2 e 6 (IL-2 e 6), fator de necrose tumoral (TNF- $\alpha$ ) e algumas enzimas anti-oxidantes [catalase, super-óxido dismutase (SOD) e glutationa peroxidase (GPX)]. Em adição foram realizadas investigações parasitológicas e histopatológicas. Nenhuma alteração foi observada nos camundongos controles normais tratados com extrato seco de cebola ou alho, individualmente ou misturado, com ou sem PZQ, comparados com os controles normais sadios. Infecção com o Schistosoma mansoni revelou um aumento em IgG, IgM, IL-2, IL-6, TNF- $\alpha$ e catalase, acompanhados de diminuição do GPX e atividade enzimática do anti-oxidante SOD. Melhora acentuada foi notada nos níveis de todos os parâmetros medidos em camundongos infectados com Schistosoma mansoni após administração dos extratos estudados. Mais ainda, significante redução na quantidade de vermes, e ovos no fígado e intestino e na contagem do oograma foi notada refletindo a normalização da arquitetura do fígado.

\section{REFERENCES}

1. Abdel-Rahman EH, Kandil OM, Abdel Megeed KN. Comparative studies of lethal effects of Bacillus thuringiensis, Allium sativum and Nerium oleander on Trichostrongylidae parasites. Egypt J Zool. 1998;30:65-79.

2. Abdualla MH, Lim KC, Sajid M, McKerrow JH, Caffrey CR. Schistsomiasis mansoni, novel chemotherapy using a cysteine inhibitor. PLoS Med. 2007;4:e14.

3. Abebe F. Novel antischistosomal drugs from medicinal plants. In: Walson RR, Preedly VR, editors. Botanical medicine in clinical practice. Cambridge: CABI; 2008. p. 175-183.

4. Abu-El-Ezz NM. Effect of Nigella sativa and Allium cepa oils on Trichinella spiralis in experimentally infected rats. J Egypt Soc Parasitol. 2005.35:511-23.

5. Ali HF. Evaluation of antioxidants effect of Citrus reticulate in Schistosoma mansoni infected mice. Trends Med Res. 2007;2;37-43.

6. Aragon AD, Imani RA, Blackburn VR, Cunningham C. Microarray based analysis of temperature and oxidative stress induced messenger RNA in Schistosoma mansoni. Mol Biochem Parasitol. 2008;162:134-41.

7. Botros SS, Sabra A, Diab T. Immunoglobulin profile in mice harbouring Schistosoma mansoni isolates showing different susceptibility to the praziquantel over different life cycle passages (snail-mouse). Egypt J Schistosomiasis Infect Dis. 2006;28:27-40.

8. Brunet LR, Dunne DW, Pearce EJ. Cytokine interaction and immune responses during Schistosoma mansoni infection. Parasitol Today. 1998;14:422-7.

9. Canals A, Zarlenga DS, Almeria S, Gasbarre LC. Cytokine profile induced by a primary infection with Ostertagia ostertagi in cattle. Vet Immunol Immunopathol. 1997;58:6375 .

10. Capron A, Dessaint JP, Capon M, Joseph M. Effector mechanisms against schistosome. In: Yamamura Y, Tada T. Progress in immunology. Tokyo: Tokyo Academic Press; 1983. p. 2,

11. Cheever AW, Anderson LA. Rate of destruction of Schistosoma mansoni eggs in tissues of mice. Am J Trop Med Hyg. 1971;20:62-8.

12. El-Shenawy NS, Soliman MF, Reyad SI. The effect of antioxidant properties of aqueous garlic extract and Nigella sativa as antischistosomiasis agents in mice. Rev Inst Med Trop Sao Paulo. 2008;50:29-36.

13. Gharib B, Abdallahi OM, Dessein H, De Reggi M. Development of eosinophil peroxidase activity and concomitant alteration of antioxidant defenses in the liver of mice infected with Schistosoma mansoni. J Hepatol. 1999;30:594-602.

14. Ghazanfari T, Hassan ZM, Ebtekar M, Ahamiani A, Naderi G, Azar A. Garlic induces a shift in cytokine pattern in Leishmania major-infected Balb/c mice. Scand J Immunol. 2000;52:491-6.

15. Ghazanfari T, Hassan ZM, Khamesipour A. Enhancement of peritoneal macrophages phagocytic activity against Leshmania major by garlic (Allium sativum) treatment. J Ethnopharmacol. 2006;103:333-7.

16. Githiori JB, Athanasiadou S, Thamsborg SM. Use of plants in novel approach for control of gastrointestinal helminthes in livestock with emphasis on small ruminants. Vet Parasitol. 2006;139:308-20.

17. Grzych JM, Capron M, Bazin H, Capron AI. In vitro and in vivo effector function of rat IgG2a monoclonal anti S. mansoni antibodies. J Immunol. 1982;129:2730-43.

18. Hamdy EL, Ahmed TH, Amin FM, Attia M, El-Rahimy HH. The role of food additives in the control of some parasites contaminating vegetables. Egypt J Parasitol. $1983 ; 13,539-49$.

19. Hamed MA. Excretory-secretory product of Fasciola hepatica worm protects against Schistosoma mansoni infection in mice. Indian J Exp Biol. 2006;44:554-61. 

53(3): 155-63, 2011.

20. Ip SP, Yiu HY, Ko KM. Differential effect of schisandrin B and dimethyl diphenyl bicarboxylate (DDB) on hepatic mitochondrial glutathione redox status in carbon tetrachloride intoxicated mice. Mol Cell Biochem. 2000;205:111-4.

21. Jia J, Zhang X, Hu Y, Wu Y, Wang Q, Li NN, et al. Evaluation of in vivo antioxidant activities of Ganoderma lucidum polysaccharides in STZ-diabetic rats. Food Chem. 2009; 115,32-6.

22. Kuntz AN, Davioud-Charvet E, Sayed AA, Califf LL, Dessoline J, Arner ES, et al. Thioredoxin glutathione reductase from Schistosoma mansoni, an essential parasite enzymes and a key drug target. PLOS Med. 2007;4:e206.

23. Kyo E, Uda N, Kasuga S, Itakura Y. Immunomodulatory effects of aged garlic extract. J Nutr. 2001;131(3s):1075S-9S.

24. Loverde PT. Do antioxidants play a role in schistosome host-parasite interactions? Parasitol Today. 1998;14:284-9.

25. Maghraby SA, Shaker KH, Zahran HG, El-Sherbiny M. In vivo, the immunological effects of Fasciola gigantica worms homogenate mixed with saponin on mice infected with Schistosoma mansoni. J Med Sci. 2007;7:724-31.

26. Mansy SS. Cellular constituent and intercellular adhesion in Schistosoma mansoni granuloma: an ultrastructural study. J Egypt Soc Parasitol. 1998;28:169-81.

27. Mantawy MM, Mahmoud AH. Effect of Allium cepa and Allium sativum feeding on glucose, glycogen, and protein bands profile and phenol oxidase activity in Biomphalaria alexandrina. J Egypt Soc Parasitol. 2002;32:271-83.

28. Metwally NS. Potency of Allium sativum and Allium cepa oils against Schistosoma mansoni infection in mice. Egypt J Hosp Med. 2006;23:319-32.

29. Mohanty JG, Jaffe JS, Schulman ES, Raible DG. A highly sensitive fluorescent microassay of $\mathrm{H}_{2} \mathrm{O}_{2}$ release from activated human leukocytes using a dihydroxyphenoxazine derivative. J Immunol Methods. 1997;202:133-7.

30. Morales-Montor J, Newhouse E, Mohamed F, Baghdadi A, Damian RT. Altered levels of hypothalamic-pituitary-adrenocortical axis hormones in baboons and mice during the course of infection with Schistosoma mansoni. J Infect Dis. 2001;183:313-20.

31. Oliver L, Stirewalt MA. An efficient method for the exposure of mice to cercariae of Schistosoma mansoni. J Parasitol. 1952;39:19-23.

32. Ozdemir G, Ozden M, Maral H, Kuskay S, Cetinalp P, Tarkun I. Malondialdehyde glutathione, glutathione peroxidase and homocysteine levels in type 2 diabetic patients with and without microalbuminuria. Ann Clin Biochem. 2005;42:99-104.

33. Pascal M, Abdallahi OM, Elwali NE, Mergani A, Qurashi MA, Magzoub M, et al Hyaluronate levels and markers of oxidative stress in the serum Sudanese subjects at risk of infection with Schistosoma mansoni. Trans R Soc Med Hyg. 2000;94:66-70.

34. Pedraza-Chaverri J, Granados-Silvestre MA, Medina-Campos ON, Maldonado PD, Olivares-Corichi IM, Ibarra-Rubio ME. Post-transcriptional control of catalase expression in garlic-treated rats. Molec Cell Biochem. 2001;216:9-19.

35. Pellegrino J, Oliveira CA, Faria J, Cunha AS. New approach to the screening of drugs in experimental Schistosomiasis mansoni in mice. Am J Trop Med Hyg. 1962;11: 201-15.
36. Pica-Mattoccia L, Orsini T, Basso A, Festucci A, Liberti P, Guidi A, et al.. Schistosoma mansoni: lack of correlation between praziquantel-induced intra-worm calcium influx and parasite death. Exp Parasitol. 2008;119:332-5.

37. Piper KP, Mott RF, McLaren DJ. Schistosoma mansoni: Histological analysis of the synergetic interaction between vaccine immunity and praziquantel therapy in the lungs of mice. Parasite Immunol. 1990;12:367-73.

38. Riad NH, Fares NH, Mostafa OM, Mahmoud YI. The effect of garlic on some parasitological parameters and on hepatic tissues reaction in experimental schistosomiasis mansoni. J Appl Sci Res. 2007;3:949-60.

39. Rivlin RS. Historical perspective on the use of garlic. J Nutr. 2001;131:951S-4S

40. Rizk M, Hafez S, Farouk H. Measurement of urea cycle enzyme activities in mice livers under the influence of different stages of Schistosoma mansoni infection and Curcuma longa extract. J Egypt Ger Soc Zool. 2000;32:319-33.

41. Simeonov A, Jadhav A, Sayed AA, Wang YH, Nelson ME, Thomas CJ. Quantitative highthroughout screen identifies inhibitors of the Schistosoma mansoni redox cascade. PLOS Negl Trop Dis. 2008;2:e127.

42. Smithers SR, Terry RJ. The infection of laboratory hosts with cercariae of Schistosoma mansoni and the recovery of worms. Parasitology. 1965;55:695-700.

43. Smolinski AT, Pestka JJ. Modulation of lipopolysaccharide-induced proinflammatory cytokine production in vitro and in vivo by the herbal constituents apigenin (chamomile), ginsenoside Rb1 and parthenolide (feverfew). Food Chem Toxicol. 2003;41:1381-90.

44. Soliman KM, El-Ansary AK, Mohamed AM. Effect of carnosine administration on certain metabolic parameters in bilharzial infected hamsters. J Egypt Soc Parasitol 2000;30:455-8

45. Son IS, Kim JH, Son KH, Kim JS, Kwon CS. Antioxidative and hypolipidemic effects of diosgenin, a steroidal saponin of yam (Dioscorea spp.), on high-cholesterol fed rats. Biosci Biotechnol Biochem. 2007;71:3063-71.

46. Streliaeva AV, Chebyshev NV, Sadykov VM. Testing CK group preparations in hymenolepiasis in white mice. Med Parazitol (Mosk.). 2000;4:33-5.

47. Sutton GA, Haik R. Efficacy of garlic as an anthelmintic in donkeys. Isr J Vet Med 1999;54:66-78.

48. Tendler M, Pinto RM, Oliveira Lima A, Gebara G, Katz N. Schistosoma manson vaccination with adult worm antigens. Int J Parasitol. 1986;16:347-52.

49. Ukeda H, Moriyama H, Kawana D, Katayama Y, Nakabayashi K, Sawamura M. Application of novel assay methods for superoxide anion-scavenging activity to food samples. Nippon Shokuhin Kagaku Kogaku Kaishi. 2002;49:25-31.

50. Warren KS, Domingo EO, Cowan RB. Granuloma formation around schistosome egg as manifestation of delayed hypersensitivity. Am J Pathol. 1967;51:735-56.

51. Warren KS. The pathology, pathobiology and pathogensis. Nature. 1978;273:609-12.

Received: 28 July 2010

Accepted: 14 February 2011 


\section{LIBRARY OF THE SÃO PAULO INSTITUTE OF TROPICAL MEDICINE}

Website: www.imt.usp.br/portal

Address: Biblioteca do Instituto de Medicina Tropical de São Paulo da Universidade de São Paulo Av. Dr. Enéas de Carvalho Aguiar, 470. Prédio 1 - Andar térreo.

05403-000 São Paulo, SP, Brazil.

Telephone: 5511 3061-7003 - Fax: 5511 3062-2174

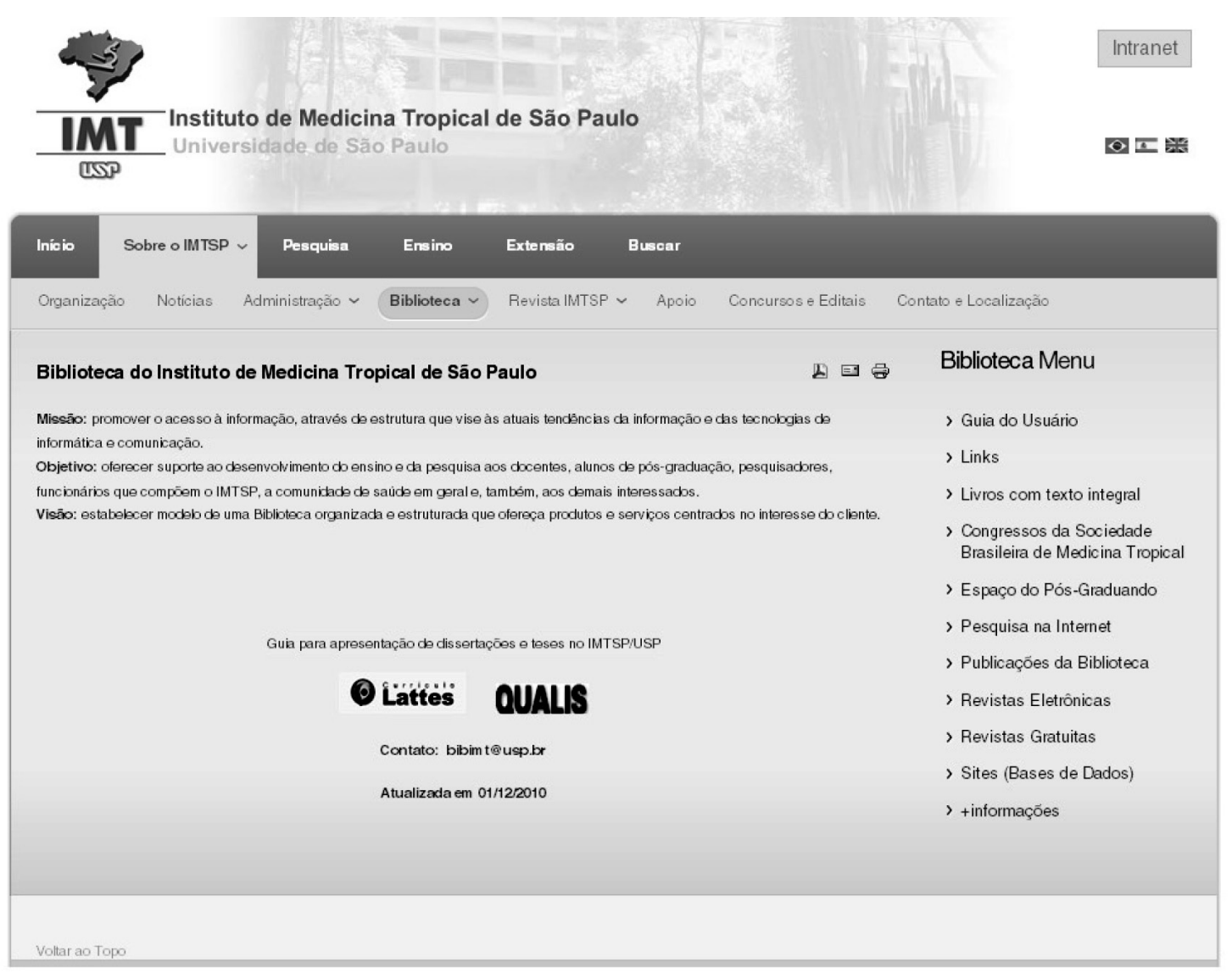

The Library of the São Paulo Institute of Tropical Medicine (IMTSP Library) was created on January 15,1959 in order to serve all those who are interested in tropical diseases. To reach this objective, we select and acquire by donation and / or exchange appropriate material to be used by researchers and we maintain interchange between Institutions thorough the Journal of the São Paulo Institute of Tropical Medicine, since the Library has no funds to build its own patrimony.

The IMTSP Library has a patrimony consisting of books, theses, annals of congresses, journals, and reference works.

The collection fo journals existing in the Library can be verified through the USP - Bibliographic Database - OPAC - DEDALUS http://dedalus.usp.br:4500/ALEPH/eng/USP/USP/DEDALUS/start of the USP network. 